The University of Southern Mississippi

The Aquila Digital Community

Faculty Publications

$5-1-2010$

\title{
Marine Fungal Diversity: A Comparison of Natural and Created Salt Marshes of the North-Central Gulf of Mexico
}

\author{
Allison K. Walker \\ University of Southern Mississippi \\ Jinx Campbell \\ University of Southern Mississippi
}

Follow this and additional works at: https://aquila.usm.edu/fac_pubs

\section{Recommended Citation}

Walker, A., Campbell, J. (2010). Marine Fungal Diversity: A Comparison of Natural and Created Salt Marshes of the North-Central Gulf of Mexico. Mycologia, 102(3), 513-521.

Available at: https://aquila.usm.edu/fac_pubs/714

This Article is brought to you for free and open access by The Aquila Digital Community. It has been accepted for inclusion in Faculty Publications by an authorized administrator of The Aquila Digital Community. For more information, please contact Joshua.Cromwell@usm.edu. 
Mycologia, 102(3), 2010, pp. 513-521. DOI: 10.3852/09-132

(C) 2010 by The Mycological Society of America, Lawrence, KS 66044-8897

\section{Marine fungal diversity: a comparison of natural and created salt marshes of the north-central Gulf of Mexico}

\author{
Allison K. Walker ${ }^{1}$ \\ Jinx Campbell \\ Department of Coastal Sciences, University of Southern \\ Mississippi, Ocean Springs, Mississippi 39564
}

\begin{abstract}
Marine fungal communities of created salt marshes of differing ages were compared with those of two reference natural salt marshes. Marine fungi occurring on the lower $30 \mathrm{~cm}$ of salt marsh plants Spartina alterniflora and Juncus roemerianus were inventoried with morphological and molecular methods (ITS T-RFLP analysis) to determine fungal species richness, relative frequency of occurrence and ascomata density. The resulting profiles revealed similar fungal communities in natural salt marshes and created salt marshes $3 \mathrm{y}$ old and older with a $1.5 \mathrm{y}$ old created marsh showing less fungal colonization. A 26 y old created salt marsh consistently exhibited the highest fungal species richness. Ascomata density of the dominant fungal species on each host was significantly higher in natural marshes than in created marshes at all three sampling dates. This study indicates marine fungal saprotroph communities are present in these manmade coastal salt marshes as early as $1 \mathrm{y}$ after marsh creation. The lower regions of both plant hosts were dominated by a small number of marine ascomycete species consistent with those species previously reported from salt marshes of the East Coast of USA.

Key words: ITS T-RFLP analysis, Juncus roemerianus, salt marsh fungi, Spartina alterniflora
\end{abstract}

\section{INTRODUCTION}

Ascomycetous fungi are the principle decomposers of the emergent salt marsh plant Spartina alterniflora (smooth cordgrass; Poaceae) (Newell 1996) and also are prevalent in the decay of Juncus roemerianus (black needlerush; Juncaceae) (Kohlmeyer and Volkmann-Kohlmeyer 2001). Together these two plant species represent the dominant Gulf Coast salt marsh vegetation (Eleuterius 1981). Lignocellulose comprises $70-75 \%$ of the organic mass of dry shoots of $S$. alterniflora (Newell and Porter 2000). Other trophic levels depend on the extracellular enzymes of saprotrophic fungi to cleave lignocellulose into

Submitted 6 May 2009; accepted for publication 29 Sep 2009.

${ }^{1}$ Corresponding author E-mail: a.k.walker@usm.edu smaller molecules that can enter the food web via mycophagic invertebrates and bacteria (Newell and Porter 2000).

Salt marshes provide critical habitat for a variety of species but are currently in decline worldwide due to a variety of natural and anthropogenic causes. Restoration efforts are under way along the northcentral Gulf Coast with nursery-raised vegetation. This study was part of a larger multitrophic search to identify assessment metrics suitable for measuring marsh restoration success. Created tidal marshes have been shown to lack organic matter and nutrients when compared with natural salt marshes (Zedler and Lindig-Cisneros 2000), so it is imperative to consider the often underappreciated role of saprotrophic fungi when restoring these systems. As the major contributor to denitrification and mineralization of carbon and nitrogen (Lillebo et al. 1999) fungi are vital to salt marsh nutrient cycling processes.

Spartina alterniflora and $J$. roemerianus do not abscise their leaves, and decay occurs while the plants are still standing (Newell and Palm 1998). Saprotrophic fungal species are well characterized for natural salt marshes of the eastern USA (Kohlmeyer and Kohlmeyer 1979, Kohlmeyer and VolkmannKohlmeyer 1991, Newell and Porter 2000). However no comparison of fungal communities has been made between natural and created salt marshes or between East Coast and Gulf Coast salt marshes of USA.

The objectives of this study were to compare marine fungal saprotroph communities among natural salt marshes and created salt marshes of different ages to determine when the marine fungal community establishes in created salt marshes and to determine whether fungal community profiles can serve as indicators of restoration success. This study also sought to provide valuable geographic distribution data for marine fungi along the understudied north-central Gulf Coast and compare the species found with those known from salt marshes of the East Coast. Effects of abiotic factors and host plant on fungal assemblages also were explored.

\section{MATERIALS AND METHODS}

Collection and morphological techniques.-Saprotrophic marine fungal species associated with standing salt marsh vegetation were inventoried with morphological and molecular techniques (ITS T-RFLP analysis) to determine ascomata density, species richness and relative frequency of 


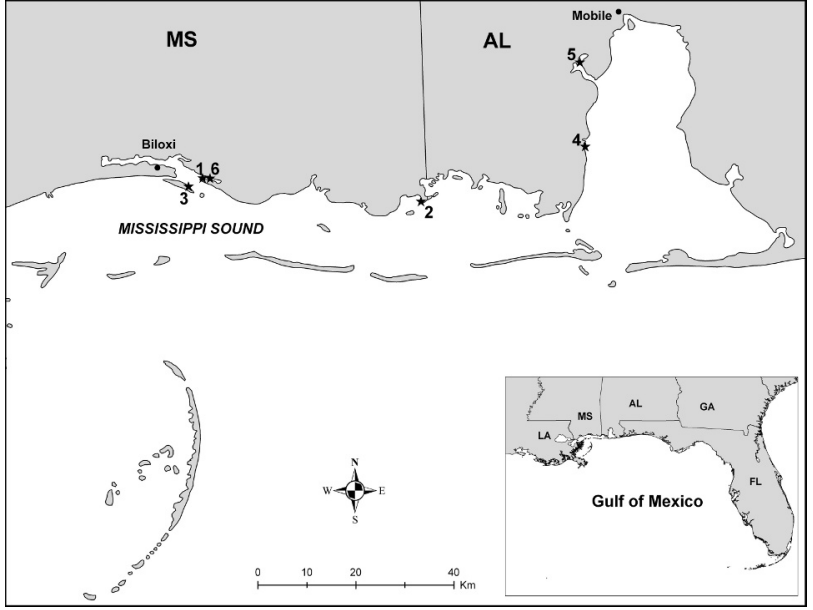

FIG. 1. Location of salt marsh sampling sites along the north-central coast of the Gulf of Mexico and created marsh age at time of collection. Natural sites: site $1=$ Shack Island, Mississippi; site 2 = Grand Bay National Estuarine Research Reserve, Mississippi. Created sites: site $3=$ Deer Island, Mississippi, 1 y; site $4=$ Mon Luis Island, Alabama, 1.5 y; site $5=$ Dog River, Alabam, 3 y; site $6=$ Davis Bayou, Mississippi, 26 y.

occurrence over three sampling seasons, fall 2005, spring 2006 and fall 2006. Because fungal species are known to exhibit a distinct vertical zonation on salt marsh plants based on halotolerance (Gessner 1977) only the lower $30 \mathrm{~cm}$ of plants was inventoried for marine fungi.

Decaying leaves of Spartina alterniflora and Juncus roemerianus were collected from two natural salt marshes and four created salt marshes along the north-central Gulf Coast (FIG. 1). Three GPS points (sites) were marked at each marsh and water temperature $(\mathrm{C}), \mathrm{pH}$, salinity (ppt) and dissolved oxygen (\%) were recorded at each site. Twelve decaying leaf blades from each plant species were collected at random in a $5 \mathrm{~m}$ radius from each GPS point, for a total of 36 leaves of each plant collected from each marsh. Leaves were placed in new resealable polyethylene bags and transported on ice to the laboratory. In the laboratory each leaf blade was cut in half with one-half used for morphology (ascomata densities, fungal identifications and isolations) and one-half used for ITS T-RFLP analysis.

Morphological identification and quantification of ascomata were carried out with light microscopy to directly observe fungal reproductive structures on decaying $S$. alterniflora and J. roemerianus. Ascomata were removed from plant leaves with the aid of a flame-sterilized needle and squash mounted in sterile distilled water or lactophenol cotton blue and examined with a Nikon Eclipse 80 microscope with Nomarski interference contrast optics. Indirect observation with the spore-trapping method of Newell (2001) also was performed. Digital photographs of microscopic fungal structures were taken with a SPOT Insight camera (Diagnostic Instruments Inc., Sterling Heights, Michigan), and measurements were made with SPOT 4.1 software (Diagnostic Instruments Inc., Sterling Heights, Michigan). Number of ascomata per $\mathrm{mm}^{2}$ leaf area of the dominant fungal species was recorded for $126 \mathrm{~cm}$ leaf blade segments from each site.

DNA extraction and sequencing.-An ascospore expulsion technique modified from Newell (2001) was used to obtain fungal single-spore isolates from leaves of both plants. Ascospores of ascomycetes that did not forcibly eject spores were isolated by nichrome-needle micromanipulation of ascomatal contents and dilution plating onto antibiotic saltwater agar (ASWA) plates. Fungal cultures were maintained in the dark at $4 \mathrm{C}$. Culture slants were maintained on saltwater potato dextrose agar (SWPDA) at $4 \mathrm{C}$.

DNA was extracted from single-spore isolates with a DNeasy Plant Mini Kit (QIAGEN, Germantown, Maryland) with the addition of lyticase (Sigma, St Louis, Missouri) following the method of Raja et al. (2003). DNA was amplified with fungal ITS primers ITS 1-F (Gardes and Bruns 1993) and ITS 4-A (Larena et al. 1999) (Invitrogen, San Diego, California). This primer pair has enhanced specificity for members of phylum Ascomycota (Larena et al. 1999), which are known to dominate the decay of standing salt marsh vegetation (Newell and Porter 2000). These primers amplified a total product of $1225 \mathrm{bp}$ which included the complete ITS region (ITS 1 and 2, and 5.8S [583 bp]), as well as the $3^{\prime}$ end of the $18 \mathrm{~S}$ and the $5^{\prime}$ end of the 28S rDNA. PCR was performed with these cycling parameters: a $3 \mathrm{~min}$ initial denaturation step at $95 \mathrm{C}$, followed by 35 cycles of $1 \mathrm{~min}$ at $95 \mathrm{C}, 30 \mathrm{~s}$ annealing at $52 \mathrm{C}$ and $1 \mathrm{~min}$ extension at $72 \mathrm{C}$, ending with a $10 \mathrm{~min}$ final extension at $72 \mathrm{C}$ in a Px2 thermal cycler (Thermo Fisher Scientific Inc., Waltham, Massachusetts). PCR products were cleaned with a QIAquick PCR purification kit (QIAGEN, Germantown, Maryland). All samples were sequenced at the University of Illinois Urbana-Champaign Core Sequencing Facility with an Applied Biosystems 3730xl DNA Analyzer. Raw sequences were edited, contiguous DNA segments were assembled and consensus sequences were exported with Sequencher 4.7 (Gene Codes Corp., Ann Arbor, Michigan). Sequences were compared with the reference sequence database NCBI GenBank with the BLAST engine (Altschul et al. 1997).

T-RFLP. - The terminal-restriction fragment length polymorphism (T-RFLP) technique was used to create sitespecific fingerprints. The ITS region of ribosomal DNA was chosen due to its highly conserved nature, combined with its high sequence variability at the species level (Larena et al. 1999). Environmental DNA was extracted from $6 \mathrm{~cm}$ leaf blades with an UltraClean ${ }^{\mathrm{TM}}$ Soil DNA Isolation Kit (MoBio Laboratories, Carlsbad, California). Fungal ITS rDNA was amplified with the fungal-specific primers ITS 1-F and ITS 4-A with ITS 1-F labeled on the $5^{\prime}$ end with the fluorescent dye FAM (6-carboxyfluorescein) (Invitrogen). Target specificity was determined by agarose gel electrophoresis and reaction yield was quantified with a NanoDrop ND-1000 spectrophotometer. PCR products were cleaned with a QIAquick PCR purification kit (QIAGEN, Germantown, Maryland), followed by restriction digestion with the HaeIII restriction enzyme (Roche Applied Science, Indianapolis, Indiana). For each sample a restriction digest reaction was set up in a $1.5 \mathrm{~mL}$ microcentrifuge tube containing either 
$10 \mathrm{ng}$ (isolate) or $100 \mathrm{ng}$ (community) purified PCR product, $1 \mu \mathrm{L} \mathrm{SuRE/Cut} \mathrm{buffer} \mathrm{M} \mathrm{(10 \times )} \mathrm{(Roche),} 1 \mu \mathrm{L}$ $(10 \mathrm{U}) \mathrm{HaeIII}$ restriction enzyme (Roche) and $\mathrm{dd}_{2} \mathrm{O}$ to equal a $10 \mu \mathrm{L}$ total reaction volume. Restriction digest reactions were incubated at $37 \mathrm{C}$ for $3 \mathrm{~h}$ with a dry bath incubator. After digestion PCR products were stored at $-20 \mathrm{C}$ until analysis. All restriction digest reagents were stored at $-20 \mathrm{C}$.

The recognition site for HaeIII is the DNA nucleotide sequence GGCC; the restriction enzyme cleaves between the second and third nucleotide $(\mathrm{G} / \mathrm{C})$, generating multiple restriction fragments for each fungal species. Only the terminal restriction fragment (T-RF) is fluorescently labeled and its size is detected by capillary electrophoresis. Buchan et al. (2002) indicated the restriction enzyme HaeIII best discriminated between salt marsh ascomycete species because the size of the T-RF produced is conserved within species yet is sufficiently variable to discriminate among species. Thus each T-RF corresponds to one fungal species and therefore the number of T-RFs in a fungal community profile can be used as a proxy for species richness.

Fragment samples were analyzed at the University of Illinois Urbana-Champaign Core Sequencing Facility with an Applied Biosystems 3730xl DNA Analyzer. Each fluorescently labeled PCR reaction was done in triplicate, and the resulting three chromatograms were overlaid for each sample with GeneMapper ${ }^{\mathrm{TM}} 3.7$ software (Applied Biosystems Inc., Foster City, California). Peaks were standardized with the Microsoft Excel-based Macro program TRFLP Tools (Stepanauskas et al. 2002). Peak height in T-RFLP chromatograms was used as a proxy for the relative abundance of fungal taxa represented by restriction fragments (Stepanauskas et al. 2003). Peaks were assumed to be artifacts and removed from analysis if they did not contribute more than $1 \%$ to the sum of peak heights in any individual profile and occurred in less than three profiles (Stepanauskas et al. 2003). In addition peaks smaller than $50 \mathrm{bp}$ or larger than $550 \mathrm{bp}$ were assumed to be primer and uncut ITS sequences, respectively, and therefore were discarded from the analyses. We compiled a list of fungal isolates obtained in this study and their T-RF sizes (TABLE II). In all 60 T-RFLP chromatograms were generated (33 from S. alterniflora, 27 from J. roemerianus). Three chromatograms were generated for each site and overlaid, resulting in 20 overlays (11 S. alterniflora, $9 \mathrm{~J}$. roemerianus), corresponding to one overlay per plant per site per collection (fall 2005, spring 2006 and fall 2006). T-RF species richness was calculated from each overlay with significant peaks as proxies for individual ascomycete species.

Statistical analyses were performed with SPSS 12 (SPSS Inc., Chicago, Illinois) with results considered significant if $P<0.05$. Datasets were tested for homogeneity of variance and normality with Levene's test for equality of variance and the Kolmogorov-Smirnov one-sample test for normality respectively. The effect of site age on fungal species richness was evaluated with linear regression. Between-site comparisons of the number of ascomata of the dominant marine saprotrophic fungal species per $\mathrm{mm}^{2}$ leaf blade were made with one-way ANOVA. Seasonal differences in ascomata density were evaluated with independent samples $t$-tests. The effect of season on fungal species richness was investigated with one-way ANOVA.

\section{RESULTS}

Six species of marine fungi were detected and identified morphologically on decaying Spartina alterniflora (TABLE I). Phaeosphaeria spartinicola was found in all collections from both natural and created salt marshes. Buergenerula spartinae (FIG. 2C) was the second most commonly encountered species, present in all collections from natural marshes and only absent from two of the created sites, Davis Bayou Island, Mississippi, (site 6) in fall 2005, and Deer Island, Mississippi, (site 3) in fall 2006. Phaeosphaeria halima was only detected in fall 2005 at one natural site, Shack Island (site 1), and one created site, Davis Bayou (site 6). Ascospores of this species were 16-17 $\times 5 \mu \mathrm{m}$ (FIG. 2A). Leptosphaeria pelagica was encountered only at one created site, Davis Bayou Island (site 2), in fall 2005.

Several of the fungal species detected in this study deviated from published descriptions or were new records for the region. Mycosphaerella sp. I and II have been documented from East Coast salt marshes for more than 28 y but have not been described formally (Kohlmeyer and Kohlmeyer 1979, Buchan et al. 2002). In the present study Mycosphaerella sp. I was detected in three collections from two natural marshes, Shack Island (site 1) in fall 2005 and Grand Bay NERR (site 2) in spring and fall 2006. This species was not detected morphologically at any of the created marshes. Mycosphaerella sp. I was described as having hyaline ascospores (Kohlmeyer and Kohlmeyer 1979), while in this study some were hyaline and some became yellow-brown with age (FIG. 2B, E), commonly noted for genus Mycosphaerella (Kohlmeyer and Kohlmeyer 1979) but not this species. Mycosphaerella sp. II was detected in five collections: from the natural site, Shack Island (site 1), in fall 2005 and spring 2006; the created sites, Deer Island (site 3), in spring 2006, Mon Luis Island (site 4), and Davis Bayou (site 6), in fall 2006 (FIGS. 1, 2D). Ascomata of Mycosphaerella sp. II were consistently encountered near ascomata of the dominant saprotrophic ascomycete $P$. spartinicola. Here we report Mycosphaerella sp. I and II from Gulf Coast salt marshes for the first time.

Five species of marine fungi were identified morphologically on Juncus roemerianus (TABLE I). Massarina ricifera was the most common marine fungal saprotroph detected on J. roemerianus and was present in all collections. Asci were bitunicate, short pedunculate, eight-spored and 71-72 × 14-15 $\mu \mathrm{m}$ 
TABLE I. Fungal species by plant host, site and season, with relative frequency of occurrence detected morphologically

\begin{tabular}{|c|c|c|c|c|c|c|c|c|c|c|c|c|c|c|c|}
\hline \multirow[b]{2}{*}{ Site: } & \multicolumn{2}{|c|}{ Fall 2005} & \multicolumn{4}{|c|}{ Spring 2006} & \multicolumn{6}{|c|}{ Fall 2006} & \multirow{2}{*}{$\begin{array}{c}\text { Relative } \\
\text { frequency } \\
\text { at natural } \\
\text { sites }(\%)\end{array}$} & \multirow{2}{*}{$\begin{array}{c}\text { Relative } \\
\text { frequency } \\
\text { at created } \\
\text { sites }(\%)\end{array}$} & \multirow{2}{*}{$\begin{array}{c}\text { Relative } \\
\text { frequency in } \\
\text { all collections } \\
(\%)\end{array}$} \\
\hline & 1 & 6 & 1 & 2 & 3 & 6 & 1 & 2 & 3 & 4 & 5 & 6 & & & \\
\hline \multicolumn{16}{|c|}{ Spartina alterniflora $(\mathrm{n}=60$ for natural sites, $\mathrm{n}=72$ for created sites) } \\
\hline \multicolumn{16}{|c|}{ Phaeosphaeria spartinicola } \\
\hline Leuchtmann & + & + & + & + & + & + & + & + & + & + & & + & 100 & 100 & 100 \\
\hline \multicolumn{16}{|l|}{ Buergenerula spartinae Kohlm. \& } \\
\hline Gessner & + & & + & & + & & + & + & + & & & + & 47 & 35 & 82 \\
\hline Mycosphaerella sp. II & + & & + & & + & & & + & & + & & & 73 & 40 & 55 \\
\hline Mycosphaerella sp. I & + & & & + & + & & & + & & & & & 17 & 10 & 27 \\
\hline \multicolumn{16}{|l|}{$\begin{array}{l}\text { Phaeosphaeria halima } \\
\text { (T.W. Johnson) Shoemaker }\end{array}$} \\
\hline \& C.E. Babc. & + & + & & & & & & & & & & & 20 & 16 & 18 \\
\hline Leptosphaeria pelagica Jones & & + & & & & & & & & & & & 0 & 17 & 9 \\
\hline \multicolumn{16}{|c|}{$\begin{array}{l}\text { Juncus roemerianus }(\mathrm{n}=48 \text { for natural sites, } \mathrm{n}=60 \text { for created sites) } \\
\text { Massarina ricifera Kohlm., }\end{array}$} \\
\hline Volkm.-Kohlm. \& O.E. Erikss. & & & + & + & + & + & + & + & & + & + & + & 100 & 100 & 100 \\
\hline \multicolumn{16}{|l|}{ Phaeosphaeria roemeriani Kohlm., } \\
\hline Volkm.-Kohlm. \& O.E. Erikss. & & & & & & & + & & & & & & 2 & 0 & 1 \\
\hline \multicolumn{16}{|l|}{ Anthostomella poecila Kohlm., } \\
\hline Volkm.-Kohlm. \& O.E. Erikss. & & & & & & & & & & & + & & 0 & 2 & 1 \\
\hline Mycosphaerella sp. & + & & & & & & & & & & & & 2 & 0 & 1 \\
\hline Leptosphaeria sp. & + & & & & & & & & & & & & 2 & 0 & 1 \\
\hline
\end{tabular}

(FIG. 2F). Ascospores were three-septate, strongly constricted at septa, hyaline to light yellow-brown, had one guttule in each section and were 21-22 $\times$ $6 \mu \mathrm{m}$ (FIG. 2G). Massarina ricifera is also common in East Coast salt marshes where it has been collected every month of the year (Kohlmeyer et al. 1995). However in the present study no gelatinous sheath was observed when ascospores were examined in India ink, contrary to the two-layered gelatinous sheath noted in the original description (Kohlmeyer et al. 1995).

Anthostomella poecila was detected only at one created site, Mon Luis Island (site 4), in fall 2006. Ascospores were brown to dark brown, broadly ellipsoidal and 14-17 $\times$ 7-9 $\mu \mathrm{m}$ (FIG. 2L). A species of Mycosphaerella was found at one of the natural sites, Shack Island (site 1), in fall 2006 and was identified to genus by its solitary, erumpent, ostiolate globose ascomata, absence of paraphyses, eight-spored elongate-cylindrical bitunicate asci and brown, one-septate 10-14 × 5-6 $\mu \mathrm{m}$ ascospores (Kohlmeyer and Kohlmeyer 1979, Kohlmeyer and Volkmann-Kohlmeyer 1991, Hyde and Sarma 2000). A BLAST analysis of the ITS rDNA of a single-spore isolate sequenced in the current study revealed a 98\% match with a Mycosphaerellaceae species isolated from Hawaiian seawater.

Leptosphaeria sp. was detected in one collection at one natural site, Shack Island (site 1), in spring 2006.
Ascomata were large, black, gregarious and emergent. Asci were 58-60 × 10-11 $\mu \mathrm{m}$ and were bitunicate and eight-spored (FIG. 2H). Ascospores were hyaline, three-septate, 16-18 $\mu \mathrm{m} \times 4 \mu \mathrm{m}$ and surrounded by a gelatinous sheath (FIG. 2I). Phaeosphaeria roemeriani was found only at one natural site, Shack Island (site 1), in fall 2006. It matched the published description (Kohlmeyer et al. 1998) except that ascospore guttules were absent (FIG. 2J, K).

The present study detected a Mycosphaerella species occupying the lower $30 \mathrm{~cm}$ of one J. roemerianus plant collected from the created site, Deer Island, Mississippi, (site 3) in spring 2006. Ascospores were on average smaller than spores of Mycosphaerella sp. II collected on S. alterniflora (10-14 $\times 5-6 \mu \mathrm{m}$ compared with $15-20 \times 5-8 \mu \mathrm{m}$ ) and were dark brown, not hyaline. The only species of Mycosphaerella reported from J. roemerianus is $M$. eurypotami, described from the upper senescing leaves and not reported from the tidally inundated region (Kohlmeyer et al. 1999). The Mycosphaerella species reported in this study does not fit the published description of $M$. eurypotami, which has ascospores 23-29 × 5.5-6.5 $\mu \mathrm{m}$; it also does not fit the published descriptions of the four other Mycosphaerella species known from the marine environment (Kohlmeyer and Kohlmeyer 1979) and therefore might be a new marine species.

A species of Leptosphaeria collected on J. roemer- 

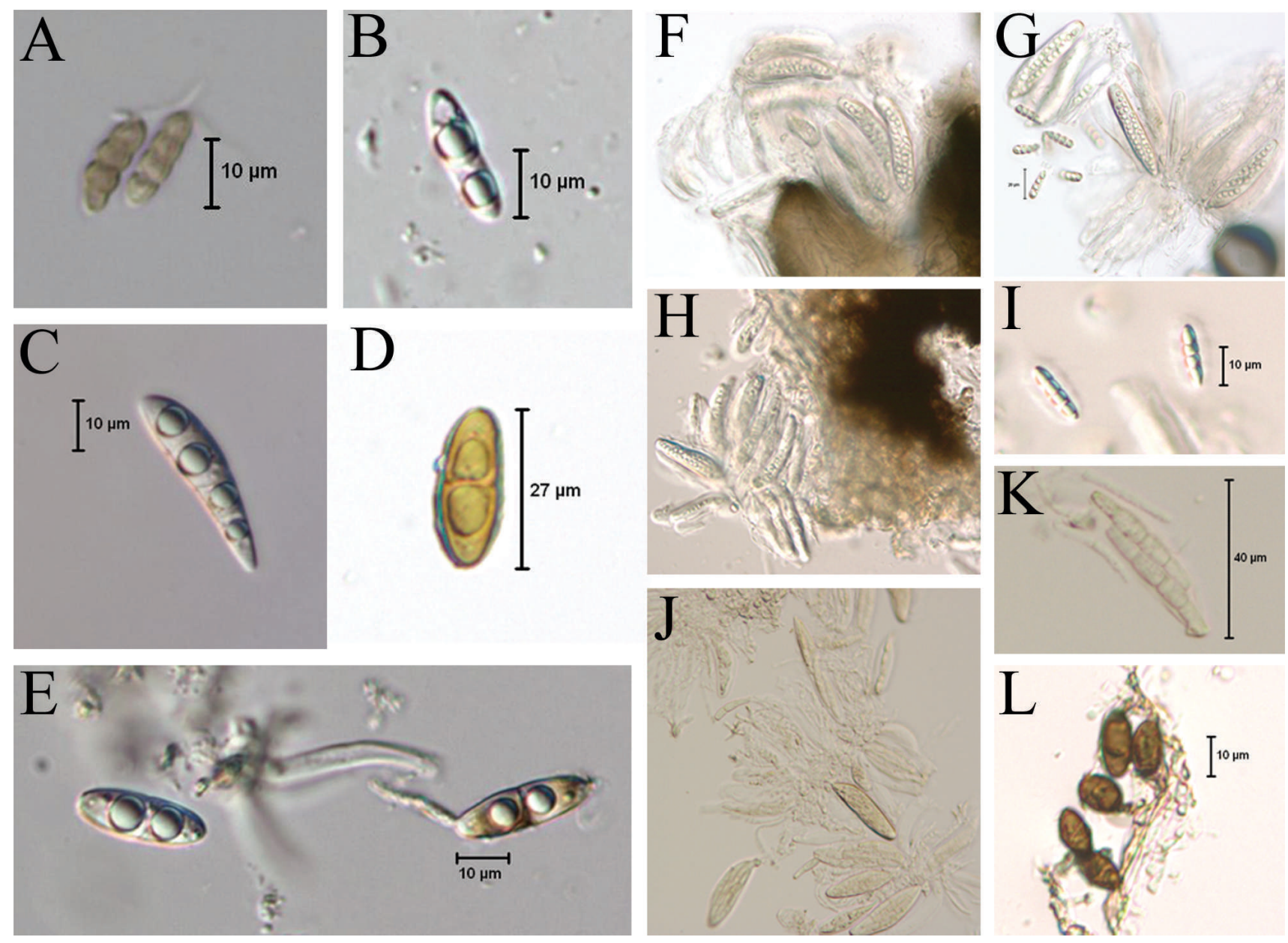

FIG. 2. A-E. Saprotrophic marine fungi on Spartina alterniflora. A. Ascospores of Phaeosphaeria halima. B. Ascospore of Mycosphaerella species I. C. Ascospore of Buergenerula spartinae. D. Ascospore of Mycosphaerella species II. E. Ascospores of Mycosphaerella sp. I. Young hyaline ascospore at left, on right older germinating ascospore is turning brown. F-L. Saprotrophic marine fungi on Juncus roemerianus. F. Ascoma and asci with ascospores of Massarina ricifera, the dominant saprotroph on J. roemerianus. G. Asci and ascospores of Massarina ricifera. H. Squash mount showing asci and ascospores of Leptosphaeria sp. I. Ascospores of Leptosphaeria sp. J. Squash mount of ascoma of Phaeosphaeria roemeriani. K. Ascospores of Phaeosphaeria roemeriani. L. Ascospores of Anthostomella poecila.

ianus in spring 2006 had hyaline 58-74 $\times 10-11 \mu \mathrm{m}$ bitunicate asci (FIG. 2H) and hyaline 16-18 $\times 4 \mu \mathrm{m}$ ascospores (FIG. 2I). Leptosphaeria marina has been reported from this host; however its asci and ascospores are respectively $112-220 \times 18-35 \mu \mathrm{m}$ and 35-68 × 8-12 $\mu \mathrm{m}$ (Kohlmeyer and Kohlmeyer 1979). The Leptosphaeria species detected on J. roemerianus in this study does not match any published description and might be a new species.

Significantly more ascomata of the dominant marine fungus Phaeosphaeria spartinicola were found on leaves of $S$. alterniflora from natural salt marshes (4.45 ascomata/ $\left.\mathrm{mm}^{2}\right)$ than from created marshes of all ages $\left(0.39\right.$ ascomata $\left./ \mathrm{mm}^{2}\right)$ (ANOVA: $\mathrm{F}=46.780$, $P=0.000) \quad(\mathrm{n}=132)$. Similarly significantly more ascomata of the dominant $J$. roemerianus saprotroph, Massarina ricifera, were found in natural marshes
(7.37 ascomata $\left./ \mathrm{mm}^{2}\right)$ than in created marshes $(1.48$ ascomata $\left./ \mathrm{mm}^{2}\right)$ (ANOVA: $\left.\mathrm{F}=955.367, P=0.000\right)(\mathrm{n}$ $=108$ ). However the mean number of ascomata produced in spring 2006 was not significantly different from the mean number of ascomata in the fall 2006 collection $[\mathrm{t}(107)=0.390, P=0.698]$.

We calculated T-RF species richness (FIG. 3). Relative abundance of dominant fungal saprotroph species based on percentage of total T-RFLP chromatogram area was calculated for one natural and one 26 y old created salt marsh in the Mississippi Sound over two seasons. For $S$. alterniflora the relative abundance of Phaeosphaeria spartinicola was 25\% at the natural marsh and $5 \%$ at the created marsh in fall 2005 and $27 \%$ at the natural and $31 \%$ at the created marsh in spring 2006. For Buergenerula spartinae the relative abundance was $4 \%$ at the natural marsh and 
A

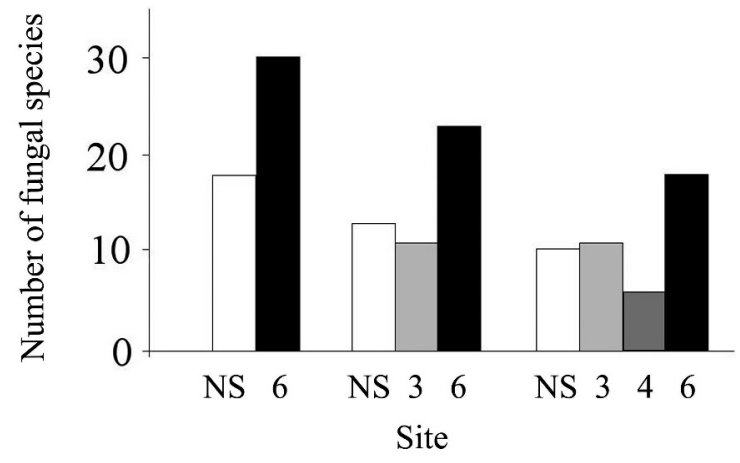

Fall 2005 Spring $2006 \quad$ Fall 2006

\section{B}

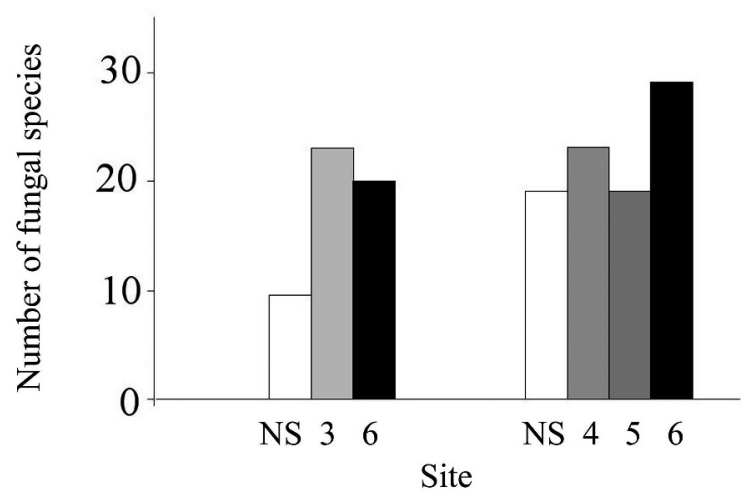

Spring 2006

Fall 2006

FIG. 3. A. Fungal species richness on decaying Spartina alterniflora at one natural salt marsh (NS) and three created salt marshes of age 1 (site 3 ), 1.5 (site 4 ) and 26 (site 6 ) y at the time of collection as determined by ITS T-RFLP analysis. B. Fungal species richness on decaying Juncus roemerianus at natural salt marshes (NS) $(\mathrm{n}=2)$ and a 1 (site 3), 1.5 (site 4), 3 (site 5) and a 26 (site 6) y old created salt marsh as determined by ITS T-RFLP analysis. Significant T-RFs were used as proxies for individual fungal species.
$10 \%$ at the created marsh in fall 2005 and $6 \%$ at both the natural and the created marsh in spring 2006. Percentages are means of three samples.

\section{DISCUSSION}

Marine fungal saprotroph communities were present in created north-central Gulf Coast salt marshes as early as $1 \mathrm{y}$ after planting. The fungal communities detected morphologically were similar to those found in East Coast salt marshes (Kohlmeyer and VolkmannKohlmeyer 2001, Buchan et al. 2002). The $S$. alterniflora fungal decay community of several East Coast salt marshes is dominated by $P$. spartinicola and Mycosphaerella sp. II (Buchan et al. 2002), while Massarina ricifera is a common saprotroph of $J$. roemerianus (Kohlmeyer et al. 1995). In the present Gulf Coast study Phaeosphaeria spartinicola and Buergenerula spartinae dominated the S. alterniflora decay community, while Massarina ricifera dominated the $J$. roemerianus decay system. Mycosphaerella sp. I on decaying S. alterniflora and Phaeosphaeria roemeriani on decaying $J$. roemerianus were collected only from natural salt marshes, suggesting that even after 26 y a created marsh has not established the same fungal community as a natural marsh. Mycosphaerella sp. II collected in this study had an ITS T-RF size of $15 \mathrm{bp}$, while in collections from Sapelo Island, Georgia, it had ITS T-RF sizes of 144, 410 and 428 bp (Buchan et al. 2002), suggesting that Gulf Coast and East Coast specimens might be different species and there might be multiple species within the East Coast specimens of Mycosphaerella sp. II.

Species richness was the first metric used to compare natural and created salt marshes. Molecular analysis revealed greater fungal species richness on both plants than was detected by morphological methods (FIG. 3A, B). The 26 y old created salt marsh at Davis Bayou Island, Mississippi, (site 6) consistently had the greatest species richness, which might indicate its fungal community contains asexual

TABLE II. Fungal isolates obtained in this study and their ITS terminal restriction fragment (T-RF) lengths

\begin{tabular}{llllr}
\hline \hline \multicolumn{1}{c}{ Species } & Isolate & Host plant & Origin & T-RF length (bp) \\
\hline Mycosphaerella sp. II & AK 110 & Spartina alterniflora & MS, USA & 15 \\
Phaeosphaeria spartinicola & AK 109 & Spartina alterniflora & MS Sound, USA & 71 \\
Aspergillus ustus & AK 117 & Spartina alterniflora & MS Sound, USA & 89 \\
Fusarium incarnatum & AK 126 & Spartina alterniflora & MS Sound, USA & 148 \\
Buergenerula spartinae & AK 112 & Spartina alterniflora & MS Sound, USA & 150 \\
Gloeotinia temulenta & AK 120 & Juncus roemerianus & Mon Luis, AL, USA & 179 \\
Mycosphaerella sp. & AK 116 & Juncus roemerianus & MS Sound, USA & 513 \\
Leptosphaeria pelagica & AK 125 & Spartina alterniflora & MS Sound, USA & 631 \\
Phaeosphaeria halima & AK 111 & Spartina alterniflora & MS Sound, USA & 656 \\
\hline
\end{tabular}


ascomycetes or yeasts that were not inventoried morphologically in this study, or additional sexual marine ascomycetes that were not fruiting at the time of collection. No significant effects of season, salinity, $\mathrm{pH}$ or dissolved oxygen on species richness were observed for either natural or created marshes.

Forty-four species of marine fungi have been detected morphologically on J. roemerianus in longterm studies (Kohlmeyer and Volkmann-Kohlmeyer 2001), while 33 species have been detected on S. alterniflora (e.g. Kohlmeyer and Kohlmeyer 1979, Leuchtmann and Newell 1991). In this study five species were detected morphologically on J. roemerianus and six on S. alterniflora. However the T-RFLP community profiles generated revealed greater species richness (23 species on each host). This agrees with the pattern observed by Buchan et al. (2002), who also detected greater diversity with the T-RFLP technique at Sapelo Island, Georgia, than from morphological methods alone. Buchan et al. (2003) found that $P$. spartinicola, P. halima, Mycosphaerella sp. II and "4clt" (an unidentified species not found in the current study) together accounted for $88 \%$ of the total T-RFLP chromatogram area in more than $70 \%$ of samples (Dean Creek, Georgia) and suggested that this native fungal decay community, dominated by only a few species, can out-compete other fungal colonizers due to its adaptation to the standing decay system. A similar mechanism might be at work in Gulf Coast salt marshes.

Morphological studies have found distinct saprotrophic fungal communities present on S. alterniflora and J. roemerianus (Newell and Porter 2000). In this study six species were detected morphologically on S. alterniflora and five on J. roemerianus, none of which was detected morphologically on both plant species. However T-RFLP community profiles revealed that more than $50 \%$ of the fungal T-RFs were found on both S. alterniflora and J. roemerianus, suggesting an overlap in fungal communities on the two host plants (TABLE III). Spartina alterniflora and J. roemerianus each yielded 23 fungal T-RFs, of which 13 fragment sizes (assumed to represent separate fungal species) were common to both plant hosts. Molecular detection of the fungi indicates their presence in both host plants examined, but the absence of ascomata of the same species on both S. alterniflora and J. roemerianus suggests that certain marine fungi might be able to colonize but not sporulate on both hosts and thus might be host specific to complete their lifecycle.

Some caveats concerning T-RFLP analysis must be noted. In cases where more than one peak was observed for the same T-RF the first peak was used to obtain a representative $\mathrm{T}-\mathrm{RF}$ size because the second peak was most likely the product of an incomplete 
restriction digest (Clement et al. 1998). If a fungal species lacks the restriction enzyme cleavage site in the ITS gene cleavage will not occur and restriction fragments will not be generated. This could account for T-RF sizes of 651 and $656 \mathrm{bp}$ (TABLE II). One solution is to use multiple restriction enzymes, each with a different restriction site. However this generates multiple community profiles, which take more time to analyze. Clement et al. (1998) found that HaelII yielded the largest number of TR-Fs when compared with three other restriction enzymes, making it the restriction enzyme of choice for this study. T-RFLP analysis can detect the presence of a species but not the absence of one (Dickie et al. 2002). In addition in some instances multiple species can have the same T-RF length; therefore T-RFLP community profiles can give only conservative estimates of species richness. Correlating T-RF size with species by morphological identification as done in this study helps to avoid biases introduced by sampling methods, fungal genomic structure and restriction enzyme characteristics (Avis et al. 2006).

Ascomata density of the principle marine fungus on each host was the second metric used to compare natural and created salt marshes. The presence of fungal ascomata is the end result of the decay process and indicates a large quantity of fungal biomass (hyphae) present within the plant (Newell and Porter 2000). The greater ascomata densities found in natural salt marshes during all three sampling seasons could indicate faster decay, which could in turn result in higher nutrient cycling within the ecosystem. Fungal productivity is nitrogen-limited in decaying S. alterniflora (Newell and Porter 2000) and created salt marshes are often nutrient poor when compared with natural salt marshes (Zedler and Lindig-Cisneros 2000), which could account for the lower ascomata densities recorded at created sites. However nutrient contents were not assessed in this study.

In conclusion saprotrophic marine fungal communities will establish rapidly in created salt marsh ecosystems but may not mirror natural communities in their composition. A combination of morphological and molecular techniques detected similar marine ascomycete communities at the natural and created north-central Gulf Coast salt marshes studied as early as $1 \mathrm{y}$ after planting. ITS T-RFLP analysis revealed higher fungal species richness on both plants than morphology alone. However the sexual marine ascomycetes inventoried morphologically in this study comprise only some of the T-RFs generated; the T-RFLP profiles also may contain asexual ascomycetes found in the marine environment. Spartina alterniflora and J. roemerianus may share more than $50 \%$ of marine fungal saprotroph species, and both were dominated by a small number of frequently occurring species. Both morphological and molecular approaches were needed to detect these patterns. Using the results of this study, saprotrophic fungal communities in additional created marshes can be examined to determine whether the marsh has an established decay community. Comparing fungal community profiles between natural and created salt marshes thus provides a qualitative measure of marsh functionality by confirming the presence of the principle decomposers of standing salt marsh vegetation.

\section{ACKNOWLEDGMENTS}

The authors thank the faculty, staff and students of the University of Southern Mississippi's Gulf Coast Research Laboratory, the staff of the Grand Bay National Estuarine Research Reserve for field assistance, A. Rossman and H. Raja for literature, and C. Park for technical assistance. Financial support from the Mississippi-Alabama Sea Grant Consortium (MASGC Grant No. R/CEH-25), the Mississippi Department of Marine Resources Tidelands Trust Fund Program (Tidelands 05-002/FY004-M0204-2) and the University of Southern Mississippi (Thesis Research Grant and Lytle Coastal Sciences Scholarship to AKW) is gratefully acknowledged.

\section{LITERATURE CITED}

Altschul SF, Madden TL, Schäffer AA, Zhang J, Zhang Z, Miller W, Lipman DJ. 1997. Gapped BLAST and PSIBLAST: a new generation of protein database search programs. Nucleic Acids Res 25:3389-3402.

Avis PG, Dickie IA, Mueller GM. 2006. A “dirty” business: testing the limitations of terminal restriction fragment length polymorphism (TRFLP) analysis of soil fungi. Mol Ecol 15:873-882.

Buchan A, Newell SY, Moreta JIL, Moran MA. 2002. Analysis of internal transcribed spacer (ITS) regions of rRNA genes in fungal communities in a southeastern U.S. salt marsh. Micro Ecol 43:329-340.

- — , Butler M, Biers EJ, Hollibaugh JT, Moran MA. 2003. Dynamics of bacterial and fungal communities on decaying salt marsh grass. Appl Environ Microbiol 69:6676-6687.

Clement BGK, Lucia E, DeBord KL, Kitts CL. 1998. Terminal restriction fragment patterns (TRFPs), a rapid, PCR-based method for the comparison of complex bacterial communities. J Microbiol Methods 31:135-142.

Dickie IA, Xu B, Koide RT. 2002. Vertical niche differentiation of ectomycorrhizal hyphae in soil as shown by $\mathrm{T}$ RFLP analysis. New Phytol 156:527-535.

Eleuterius LN. 1981. An illustrated guide to tidal marsh plants of Mississippi and adjacent states. MississippiAlabama Sea Grant Consortium publication No. MASGP-77-039. 131 p.

Gardes M, Bruns TD. 1993. ITS primers with enhanced 
specificity for basidiomycetes-application to the identification of mycorrhizae and rusts. Mol Ecol 2:113118.

Gehring CA, Theimer TC, Whitham TG, Keim P. 1998. Ectomycorrhizal fungal community structure of pinyon pines growing in two environmental extremes. Ecology 79:1562-1572.

Gessner RV. 1977. Seasonal occurrence and distribution of fungi associated with Spartina alterniflora from a Rhode Island estuary. Mycologia 69:477-491.

Hyde KD, Sarma VV. 2000. Pictorial key to higher marine fungi. In: Hyde KD, Pointing SB, eds. Marine mycology-a practical approach. Hong Kong: Fungal Diversity Press. p 205-270.

Kohlmeyer J. 1963. Fungi marini novi vel critici. Nova Hedwig 6:297-329.

—_, Gessner RV. 1976. Buergenerula spartinae sp. nov., an ascomycete from salt marsh cordgrass, Spartina alterniflora. Can J Bot 54:1759-1766.

— fungi. New York: Academic Press. 690 p.

, Volkmann-Kohlmeyer B. 1991. Illustrated key to the filamentous higher marine fungi. Bot Mar 34:1-61.

- -1995 . Fungi on Juncus roemerianus 4. New marine ascomycetes. Mycologia 87:532-542. . 1998. Fungi of Juncus roemerianus 11. More new ascomycetes. Can J Bot 76:467-477.

1999. Fungi on Juncus roemerianus 12. Two new species of Mycosphaerella and Paraphaeosphaeria (Ascomycotina). Bot Mar 42:505-511.

— - 2001. The biodiversity of fungi on Juncus roemerianus. Mycol Res 105:1411-1412.

Larena I, Salazar O, Gonzalez V, Julian MC, Rubio V. 1999. Design of a primer for ribosomal DNA internal transcribed spacer with enhanced specificity for ascomycetes. J Biotechnol 75:187-194.
Leuchtmann A, Newell SY. 1991. Phaeosphaeria spartinicola, a new species on Spartina. Mycotaxon 41:1-7.

Lillebo AI, Flindt MR, Pardal MA, Marques JC. 1999. The effect of macrofauna, meiofauna and microfauna on the degradation of Spartina maritima detritus from a salt marsh area. Acta Oecolog 20:249-258.

Newell SY. 1996. Established and potential impacts of eukaryotic mycelial decomposers in marine/terrestrial ecotones. J Exp Mar Biol Ecol 200:187-206.

- 2001. Spore-expulsion rates and extents of blade occupation by ascomycetes of the smooth-cord grass standing-decay system. Bot Mar 44:277-285.

— on standing-decaying blades of smooth cord grass to additions of water and nitrogen. Int Rev Hydrobiol 83: 115-122.

— from salt marsh-grass shoots, and its known and potential fates. In: Weinstein MP, Kreeger DA, eds. Concepts and controversies in tidal marsh ecology. Dordrecht: Kluwer. p 159-185.

Raja HA, Campbell J, Shearer CA. 2003. Freshwater ascomycetes: Cyanoannulus petersenii, a new genus and species from submerged wood. Mycotaxon 88:117.

Stepanauskas R, Henriksen JR, Gonzalez JM. 2002. Excelbased Macro program TRFLP Tools version 6 Sep 2002, UGA, Univ Laguna, Mexico.

-, Moran MA, Bergamaschi BA, Hollibaugh JT. 2003. Covariance of bacterioplankton composition and environmental variables in a temperate delta system. Aquat Microb Ecol 31:85-98.

Zedler JB, Lindig-Cisneros R. 2000. Functional equivalency of restored and created salt marshes. In: Weinstein MP, Kreeger DA, eds. Concepts and controversies in tidal marsh ecology. Dordrecht: Kluwer. p 569-582. 